\title{
Multi-functional effects of textiles dyed with madder roots powder (Rubiatinctoria)
}

\section{REZUMAT - ABSTRACT}

\section{Efectele multifuncționale ale textilelor vopsite cu extract din rădăcină de roibă (Rubiatinctoria)}

În acest studiu, tricotul de $100 \%$ bumbac a fost supus tratamentului preliminar de mordansare cu tanin de mimoză și tanin de mimoză/alaun și vopsit cu un colorant extras din rădăcină de roibă. Gradul de epuizare a fost realizat prin spectroscopie UV-Vis. Rezistența culorii la lumină, spălare, frecare (umedă și uscată) și transpirația țesăturilor mordansate și vopsite au fost evaluate conform standardului ISO specific.

Probele au fost testate la protecția împotriva radiațiilor ultraviolet și activitatea antibacteriană împotriva tulpinilor de Staphylococcus aureus. Rezistența culorii la spălare și lumină sunt slabe, iar rezistența la transpirație și frecare este moderată. Țesăturile vopsite demonstrează un efect excelent de protecție UV și o bună activitate antibacteriană. Chiar și subțiri, materialele utilizate pentru hainele de vară vopsite cu roibă ar putea oferi un mijloc eficient și comun de a proteja corpul uman împotriva efectelor nocive ale radiațiilor ultraviolete.

Cuvinte-cheie: colorant natural, tanin de mimoză, alaun, protecție UV, activitateantimicrobiană

\section{Multi-functional effects of textiles dyed with madder roots powder (Rubiatinctoria)}

In this study, 100\% cotton knit was premordanted with mimosa tannin and mimosa tannin/alum and dyed with a dyestuff extracted from Madder root. The degree of exhaustion was carry out by UV-Vis spectroscopy. The color fastness to light, wash, rubbing (wet and dry) and perspiration of the mordanted and dyed fabrics were evaluated according to specific ISO standard.

The samples were tested for ultraviolet protection and antibacterial activity against Staphylococcus aureus strains. The color fastness to washing and light are poor and the fastness to perspiration and rubbing is moderate. The dyed fabrics demonstrate an excellent UV protective effect and a good antibacterial activity. Even thin, the materials used for summer clothes dyed with madder could provide an effective and common mean to protect the human body against the harmful effects of UV rays.

Keywords: natural dye; mimosa tannin; alum, UV protection; antimicrobial activity

\section{INTRODUCTION}

Rubiatinctorum also called madderis one of the oldest dye used in paintings, for textiles and leather dyeing [1-2]. The extract of madder roots contains up 36 anthraquinone compounds [3]. The main 15 color components extracted from the root of Rubia Tinctoria are grouped together in the Colour Index as C. I. Natural Red 8, among which the most important ones are alizarin, purpurin, xanthopurpurin, rubiadin, pseudopurpurin, munjistin, lucidin and, the glycosidic compounds ruberythric acid and lucidinprimeveroside [4-5].

The main issues raised by the use of natural dyed textiles are the effects on human health and the environment and coloristic resistance to wearing and maintenance.

In Ayurvedic medicine, Indian madder is used as an immune regulator, blood purifying herb, antioxidant, to regulates blood pressure and blood vessel constriction, treatment of kidney and bladder stones, laxative, mild sedative [6]. Rubiatinctorum is used as antifungal [7] and antimicrobial [8] medicine and has antioxidant capacity superior to $1 \mathrm{~m}$ MTrolox equivalent (hydrosoluble form of vitamin E) [9].

Even former studies reported a mutagenic potential of RubiaTinctorium [10-11] due to 1,3-dihydroxyanthraquinones which bear a methyl orhydroxymethyl group on carbon-2 such as lucidin [12], new scientific researches demonstrate the lack of dye'cytotoxic activity [9].

More than that the, absorbing in UV region, the materials dyed with madder could provide an effective and common mean to protect the human body against the harmful effects of UV rays, such as premature aging and skin cancers [13-14].

Along the time different recipes were used to dye cotton with madder roots, the most renown being the Turkey red process involving 7 up to 20 stages [15]. Being a so complex process, different others synthetic and natural mordants are used to increase the fixation of the dye and to improve the light/wash fastness of the dyestuff compounds. 
The aim of this research was to investigate the effect of mordants on dyeing fastness, the UV protection and antibacterial activity of cotton knit dyed with MadColor, extracted from Madder root.

\section{MATERIALS}

Textile material: chemically bleached $100 \%$ cotton knit with weight of $165 \mathrm{~g} / \mathrm{m}^{2}$, yarn fineness: $59.2 \pm 5.2 \mathrm{Nm}$, thickness: $0.79 \mathrm{~mm}$.

Dye: Mad-Color: dyestuff extract of Madder root (Rubiatinctoria); dyestuff content: $110 \mathrm{~g} / \mathrm{Kg}$; supplied by NIG Nahrungs-Ingenieurtechnik $\mathrm{GmbH}$, Austria.

Mordents: alum $\left(\mathrm{KAl}\left(\mathrm{SO}_{4}\right)_{2} \cdot 12 \mathrm{H}_{2} \mathrm{O}\right)$ from SigmaAldrich; mimosa tannin powder supplied by Silva Chimica (St Michele Mondovi, Italy); it contains 80-82\% flavonoid monomers and oligomers (robinetinidin, fisetinidin, catechin, delphinidin), $1 \%$ of amino and imino acids, carbohydrates.

Mordanting and dyeing process: The cotton knit was pre-mordanted with mimosa tannin and alum for one hour $30-40^{\circ} \mathrm{C}$ and 3 hours at ambient temperatura. The mordanted fabrics were dyed with $4 \% \mathrm{Mad}$ Color on weight of fibre (owf) foronehour at $80^{\circ} \mathrm{C}$, maintaining the liquor ratio $1: 25$ and then allowed to cool down, rinsed with clean water and air-dried.

\section{CHARACTERIZATION}

UV-Vis spectroscopy (UV-VIS-NIR Perkin Elmer Lambda 950 spectrophotometer) was used to determine the maximum absorption specific of dyes and mimosa tannin and to evaluate the degree of exhaustion representing the amount of dyestuff or mordant diffused in the fibers.

The color fastness of mordanted and dyed fabrics were evaluated according to ISO standards: colour fastness to washing (ISO 105-C06:2010), alkaline and acid perspiration (ISO 105-E04:2013), rubbing (ISO 105-F09:2009) and color fastness to light (ISO 105-B02:1999).
Ultraviolet protection factor (UPF) was measured on UV-VIS spectrophotometer (Cary 50, Varian, Australia) fitted with an Diffuse Reflectance Accessoryacross the wavelength range 280 to $390 \mathrm{~nm}$. Thereported values are the average of eight measurements made on sub-samples taken from the fabrics. The samples were tested for microbial activity in Staphylococcus aureus according to SR EN ISO 20645/2005. Textile fabrics - Determination of antibacterial activity Agar diffusion plate test.

\section{RESULTS AND DISCUSSIONS}

\section{The appearance of mordanted and dyed} materials

The appearance of mordanted and dyed materials are shown in the table 1.

The mimosa tannin colors the fabrics in brown-yellow, the shade becoming darker as the tannin concentration increases. The alum gives lighter shades to fabrics. The red color of the fabrics mordanted with mimosa tannin and dyed with extract from Rubia Tinctoria could be attributed to tannins, polyphenolics compounds and polysaccharide and free sugars [16]. The red-orange and orange colors of the fabrics mordanted with $2 \%$ mimosa $/ 4 \%$ alum and respectively $8 \%$ mimosa $/ 15 \%$ alum and dyed with Rubia are due to the arrangement of anthraquinone structures around the aluminum cation used in the pre-mordanting process. Other studies show that the yelloworange color could be determined by the high content of heterosidic dyes such as are lucidinprimeveroside, ruberythric acid (alizarin primeveroside), galiosin (pseudopurpurinprimeveroside) and rubiadinprimeveroside [17]. The aglycones compounds (alizarin, purpurin, pseudopurpurin, lucidin, xanthopurpurin and rubiadin) induce a more orange-red color.

\section{UV-VIS spectra of Mad-Color}

The UV-VIS spectra of the $0.143 \mathrm{~g} / \mathrm{L}$ Mad-Color dye is shown in the figure 1.

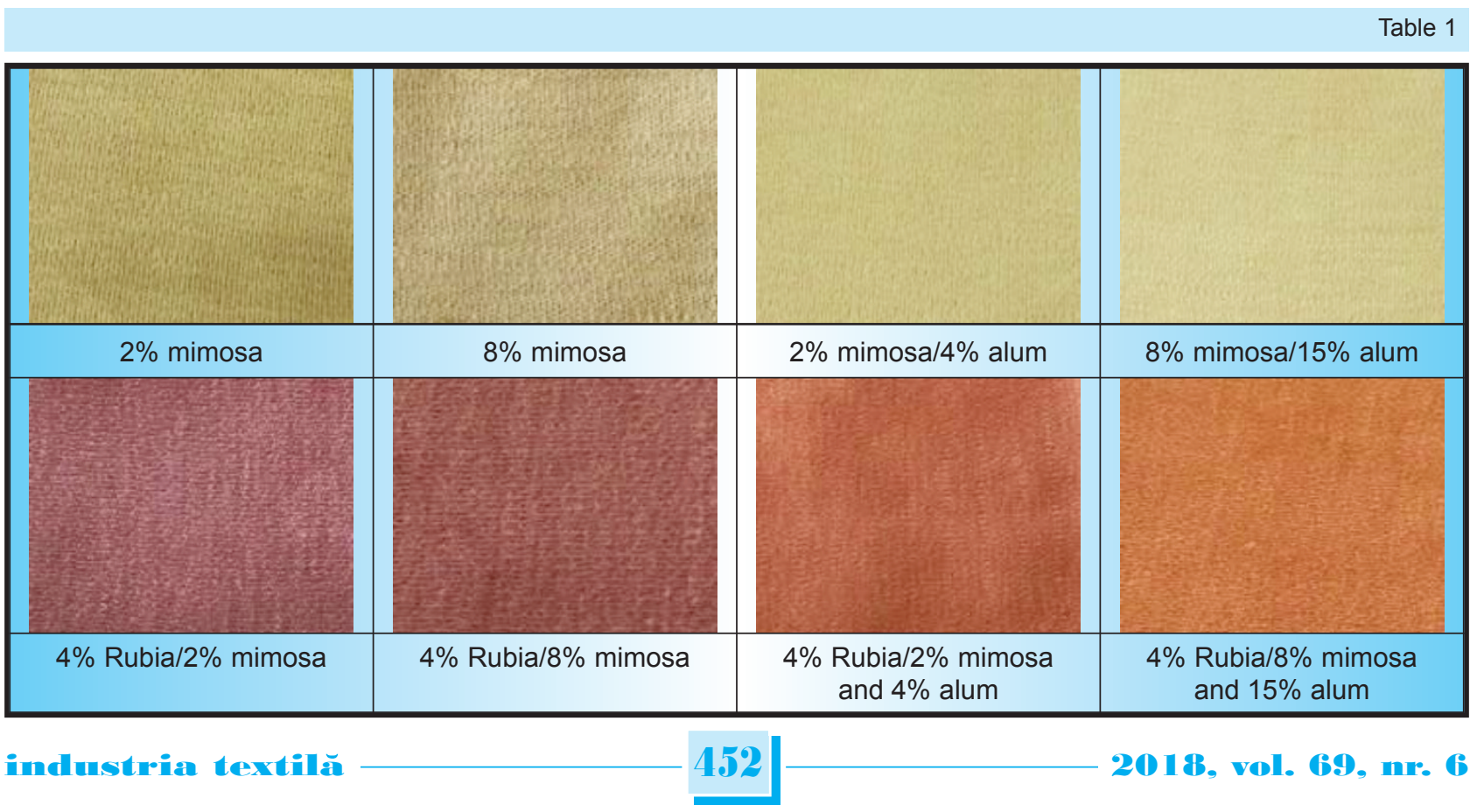




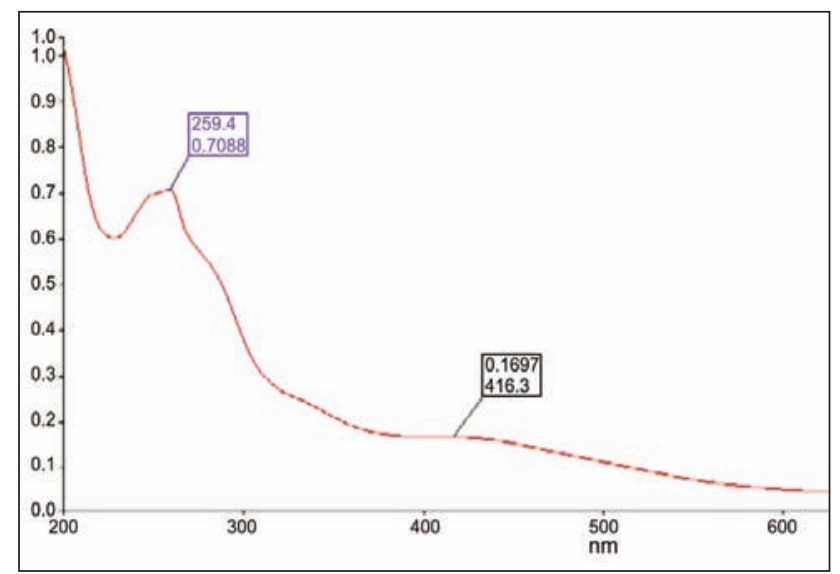

Fig. 1. UV-VIS absorption spectrum of Mad-Color

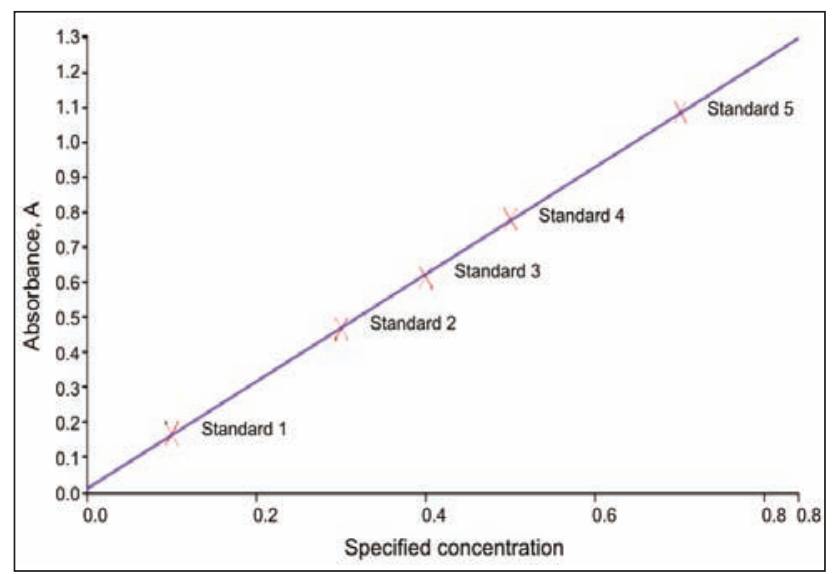

Fig. 2. Calibration curve of Mad-Color at $\lambda \max =416 \mathrm{~nm}$

Table 2

\begin{tabular}{|c|c|c|c|c|}
\hline Sample & $\begin{array}{c}\text { The dyebath resulting from dyeing } \\
\text { the cotton knit mordanted with: }\end{array}$ & $\begin{array}{c}\text { Initial concentration, } \\
\mathbf{g} / \mathbf{L}^{*}\end{array}$ & $\begin{array}{c}\text { Final Concentration, } \\
\mathbf{g} / \mathbf{L}^{* *}\end{array}$ & $\begin{array}{c}\text { The dyebath } \\
\text { exhaustion }\end{array}$ \\
\hline 1 & $8 \%$ Mimosa & 0.3887 & 0.4359 & -12.14 \\
\hline 2 & $2 \%$ Mimosa & 0.3988 & 0.4074 & -2.15 \\
\hline 3 & $8 \%$ Mimosa, 15\% Alum & 0.4243 & 0.5053 & -19.09 \\
\hline 4 & $2 \%$ Mimosa, 4\% Alum & 0.3607 & 0.5011 & -38.92 \\
\hline
\end{tabular}

* Initial concentration represents the concentration of $4 \%$ Mad-Color solution used to dye the cotton

** Final concentration represents the concentration of Mad-Color dyebath solutions after dyeing of cotton mordanted with different mordants.

The aqueous solution of Mad-Color (RubiaTinctoria extract) has two maxima absorption peaks at $259 \mathrm{~nm}$ and $416 \mathrm{~nm}$, representing the absorption of acetophenone- and benzoquinone chromophores. The absorption at $259 \mathrm{~nm}$ is caused by the electron transfer bond in the benzenoid ring and one keto group and the absorption at $416 \mathrm{~nm}$ is due to the local excitation bond of the $\mathrm{C}=\mathrm{O}$ of the quinone chromophore [18].

The anthraquinone compounds with $\lambda$ max near to that found by us include ruberythric acid (406 nm), lucidinprimeveroside $(415 \mathrm{~nm})$ and alizarin $(424 \mathrm{~nm})$ [19-20].

For the Rubia dye components, other literature data [21] indicate the absorption maxima at $\lambda \max =198$, $249,279 \mathrm{~nm}, 423 \mathrm{~nm}$ for alizarin, at $\lambda \max =255,292$, 479,485 and $512 \mathrm{~nm}$ for purpurine [22] 493 and $460 \mathrm{~nm}$ for pseudopurpurine, $\lambda \max =224,256,415$ $\mathrm{nm}$ for ruberythric acid and $\lambda \max =200,246,285$, $406 \mathrm{~nm}$ for lucidinprimeveroside. Considering this data, it is assumed that the main components of the coloring powder used could bea mixture of ruberythricacid, lucidinprimeveroside and alizarine.

During the dyeing process, the ruberythric acid and the lucidinprimeveroside are usually hydrolyzed to alizarin and lucidin. Lucidin is hardly detected in dyed textiles [23], due to its oxidation to nordamnacanthol in the presence of oxygen by endogenous enzymes [24] or its enzymatically transformation to a quinone groups [25].

\section{Dye-bath exhaustion}

Absorbance of the dyebath solutions before and after dyeing was measured at $\lambda \max =416 \mathrm{~nm}$.

For the determination of the concentration, a calibration curve was made in 5 points $(0.1 \mathrm{~g} / \mathrm{L}, 0.3 \mathrm{~g} / \mathrm{L}$, $0.4 \mathrm{~g} / \mathrm{L}, 0.5 \mathrm{~g} / \mathrm{L}, 0.7 \mathrm{~g} / \mathrm{L}$ dye) at $416 \mathrm{~nm}$ (figure 2).

The percentage dye-bath exhaustion $(E \%)$ was calculated using equation 1 :

$$
E \%=100 \times\left(1-C_{1} / C_{0}\right)
$$

where: $C_{0}$ and $C_{1}$ represent the concentration of dye solution before and after dyeing, respectively.

The concentrations of the initial and final solutions of Mad-Color recorded at $\lambda \max =416 \mathrm{~nm}$ are displayed in the table 2.

The slight variation in the initial concentration of the dye solution from $0.3607 \mathrm{~g} / \mathrm{L}$ to $0.4243 \mathrm{~g} / \mathrm{L}$ is determined by the large number of compounds present in the Mad-Color powder, responsible for the different shades obtained almost in the same conditions [26]. Higher final concentration values than the initial ones demonstrate that the after dyebath contains both the color components of Mad-Color and probably, mimosa tannin compounds with structures similar to the dye components that migrate from the material to the solution during dyeing.

This hypothesis is confirmed by higher concentrations of the final solutions resulting from the dyeing of the fabrics mordanted with $8 \%$ mimosa tannin than those mordanted with $2 \%$ mimosa tannin. On the other hand, a higher concentration of tannin implies a larger number of occupied active sites which are no 
longer available for the absorption of the dye which remains in solution.

The addition of alum does not have a positive effect on the degree of exhaustion. Certain studies [27] have shown that although aluminum has the role of fixing low molecular weight compounds (e.g., alizarine molecules) to the substrate in the case of higher molecular weight molecules such as glycosylated compounds, aluminum hindered the dyeing process. As has been shown, the basic component of MadColor dye is lucidinprimeveroside, a glycoside having two sugar moieties attached to the anthraquinone structure. Due to its increased steric bulk, it could limit the number of molecules that are able to arrange around the aluminum ion and, therefore lowers the exhaustion degree.

\section{Colour fastness of knits dyed with Mad-Color}

Evaluation of colour fastness of knits dyed with MadColor is presented in table 3.

The Indian standard requirements for minimum change in colour of natural Rubiadye on cotton fabric to washing, light and rubbing is $4-5$, and to perspiration is 3 [28]. Our results demonstrate a very low fastness rating to washing, and light, regardless of the type and concentration of mordants used. The perspiration fastness is slightly better for knit mordanted with $8 \%$ mimosa and $15 \%$ alum, not because of the dye itself but because the knit is dyed with a smaller amount of dye and consequently, a less amount of dye migrates from the material in solution. Rubbing fastness, especially dry rubbing, is high.

\section{Ultra violet radiation (UPF) protection factor} assessment of materials dyed with Mad-Color

The values of the sun protection factor and of the transmissions in the UVA and UVB regions are presented in table 4.

According to Australia/New Zealand Standard AS/NZS 4399:1996, the textilescould provide a good protection if UPF is 15,20 , very good protection if UPF is $25,30,35$, or excellent protection if UPF is 40 , $45,50,50+$.

Having a UPF equal to 10, the white knit doesn't provide any protection against UV rays. Instead, the same material mordanted with mimosa tannin and dyed with Mad-Color ensures an excellent UV protection no matter the type or concentration of mordants.

It has been shown that alizarin in the madder dye improves the UV protective effect of textiles due to its absorption in the UV region $(\lambda \max =250 \mathrm{~nm})$ [29].

Table 3

\begin{tabular}{|c|c|c|c|c|c|}
\hline \multicolumn{2}{|c|}{ Fastness to: /Sample } & \multirow{2}{*}{$\frac{\mathbf{R}+\mathbf{8} \% \text { mimosa }}{1}$} & \multirow{2}{*}{$\frac{R+2 \% \text { mimosa }}{1}$} & \multirow{2}{*}{$\begin{array}{c}\mathbf{R}+\mathbf{8 \%} \text { mimosa } \\
15 \% \text { alum }\end{array}$} & \multirow{2}{*}{$\begin{array}{c}\mathbf{R}+2 \% \text { mimosa }+ \\
\mathbf{4 \%} \text { alum }\end{array}$} \\
\hline W/gahing & color change & & & & \\
\hline vasning & color staining* & $4 / 4-5 / 4 / 4-5 / 4-5 / 4$ & $3-4 / 4-5 / 3-4 / 4-5 / 4-5 / 3-4$ & $3-4 / 4-5 / 3-4 / 4 / 4-5 / 4$ & $4 / 4-5 / 4 / 4-5 / 4-5 / 4$ \\
\hline \multirow{2}{*}{$\begin{array}{l}\text { Acidic- } \\
\text { perspiration }\end{array}$} & color change & $1-2$ & 2 & $2-3$ & 2 \\
\hline & color staining ${ }^{*}$ & $2-3 / 2 / 1-2 / 3 / 2-3 / 2-3$ & $2-3 / 2-3 / 1-2 / 3 / 2-3 / 2-3$ & $2-3 / 2 / 2-3 / 3 / 2-3 / 3$ & $2-3 / 2 / 2-3 / 3 / 2-3 / 3$ \\
\hline \multirow{2}{*}{$\begin{array}{l}\text { Alkaline- } \\
\text { perspiration }\end{array}$} & color change & $2-3$ & 3 & 4 & $3-4$ \\
\hline & color staining* & $2-3 / 2 / 1-2 / 3 / 2-3 / 2-3$ & $2-3 / 2-3 / 1-2 / 3 / 2-3 / 2-3$ & $2-3 / 2 / 2-3 / 3 / 2-3 / 3$ & $2-3 / 2 / 2-3 / 3 / 2-3 / 3$ \\
\hline \multirow{2}{*}{ Rubbing } & dry & $4-5$ & $4-5$ & $4-5$ & $4-5$ \\
\hline & wet & 3 & $3-4$ & 3 & 3 \\
\hline \multirow{2}{*}{ Light } & Gray scale & $3^{* *}$ & $3^{* * *}$ & $3^{* * *}$ & $3^{* * *}$ \\
\hline & Blue scale & 3 & 3 & 3 & 3 \\
\hline
\end{tabular}

*Diacetate/Cotton/Polyamide/Polyester/Acryl/Wool; Exposure time: ** -14 hours; ${ }^{* * *}-7$ hours.

Table 4

\begin{tabular}{|c|c|c|c|c|c|}
\hline Samples & Mean UPF & $\begin{array}{c}\text { Mean UVA } \\
\text { Transmission }\end{array}$ & $\begin{array}{c}\text { Mean UVB } \\
\text { Transmission }\end{array}$ & $\begin{array}{l}\text { Calculated } \\
\text { UPF }\end{array}$ & UPF rating \\
\hline undyed (white) Cotton & 13.051 & 10.152 & 7.145 & 11.829 & 10 \\
\hline knitmordanted with $2 \%$ mimosa & 316.134 & 0.234 & 0.278 & 277.242 & $50+$ \\
\hline $\begin{array}{l}\text { knitmordanted with } 2 \% \text { mimosa and dyed } \\
\text { with Mad Color }\end{array}$ & 216.930 & 0.507 & 0.434 & 153.174 & $50+$ \\
\hline knitmordanted with $8 \%$ mimosa & 179.150 & 0.775 & 0.493 & 150.111 & $50+$ \\
\hline $\begin{array}{l}\text { knitmordanted with } 8 \% \text { mimosa and dyed } \\
\text { with Mad Color }\end{array}$ & 140.793 & 0.947 & 0.636 & 125.532 & $50+$ \\
\hline knitmordanted with $2 \%$ mimosa $4 \%$ alum & 418.690 & 0.175 & 0.186 & 350.775 & $50+$ \\
\hline $\begin{array}{l}\text { knitmordanted with } 2 \% \text { mimosa } 4 \% \\
\text { alumand dyed with Mad Color }\end{array}$ & 229.963 & 0.402 & 0.406 & 194.800 & $50+$ \\
\hline knitmordanted with $8 \%$ mimosa $15 \%$ alum & 412.343 & 0.077 & 0.211 & 296.006 & $50+$ \\
\hline $\begin{array}{l}\text { knitmordanted with } 8 \% \text { mimosa } 15 \% \text { alum } \\
\text { and dyed with Mad Color }\end{array}$ & $\begin{array}{c}1376.710 \\
(1047.600)\end{array}$ & $\begin{array}{c}0.244 \\
(0.111)\end{array}$ & $\begin{array}{c}0.077 \\
(0.084)\end{array}$ & $\begin{array}{c}586.236 \\
(497.602)\end{array}$ & $\mathrm{P}+$ \\
\hline
\end{tabular}


The dyeing of knit mordanted with $2 \%$ mimosa, basically leads to UVA radiation blocking (only 0.234 being transmitted) and to the penetration of a reduced amount of UVB rays $(0.434)$ providing excellent protection for the human body.

If dyeing is done on a knit mordanted with $8 \%$ mimosa, the amount (0.947) of UVA rays penetration increases slightly compared to knitted mordanted with $2 \%$ mimosa and dyed, providing an excellent protection (UPF > 50+). The effective UV transmission trough the fabrics required by the AS/NZS 4399:
1996 standard is from 6.7 to 4.2 for a good protection, from 4.1 to 2.6 for a very good protection and less than 2.5 for an excellent protection.

If only the UV rays on UVA domain penetrating the fabrics are considered, is observed that the smallest amounts of radiation are transmitted through the fabrics mordanted with $8 \%$ mimosa and $15 \%$ alum (Mean UVA Transmission $=0.077$ ) and through the fabric mordanted with $8 \%$ mimosa $15 \%$ alum and dyed with Mad Color 2\% mimosa (Mean UVA Transmission = 0.111). If only the amount of transmitted UVB radiation

\begin{tabular}{|c|c|c|c|c|c|}
\hline \\
\hline \multicolumn{6}{|c|}{$\begin{array}{l}\text { THE MICROGRAPHS OF ANTIBACTERIAL ACTIVITY OF UNDYED AND DYED FABRICS AGAINST } \\
\text { STAPHYLOCOCCUS AUREUS }\end{array}$} \\
\hline Sample & $\begin{array}{l}\text { Inhibition zone } \\
(\mathrm{mm})\end{array}$ & Growth & Description & Evaluation & Picture \\
\hline Control & 0 & Moderate & $\begin{array}{l}\text { Without the } \\
\text { inhibition zone }\end{array}$ & Insufficient effect & \\
\hline $\begin{array}{l}\text { Mordanted with } \\
2 \% \text { mimosa }\end{array}$ & 0 & Small & $\begin{array}{l}\text { Without inhibition } \\
\text { zone, some } \\
\text { restricted colonies }\end{array}$ & Limited efficacy & \\
\hline $\begin{array}{l}\text { Mordanted with } \\
8 \% \text { mimosa }\end{array}$ & 0 & Small & $\begin{array}{l}\text { Without inhibition } \\
\text { zone, some } \\
\text { restricted colonies }\end{array}$ & Limited efficacy & \\
\hline $\begin{array}{l}\text { Mordanted with } \\
2 \% \text { mimosa / } \\
4 \% \text { alum }\end{array}$ & 0 & Small & $\begin{array}{l}\text { Without inhibition } \\
\text { zone, some } \\
\text { restricted colonies }\end{array}$ & Limited efficacy & \\
\hline $\begin{array}{l}\text { Mordanted with } \\
8 \% \text { mimosa / } \\
15 \% \text { alum }\end{array}$ & 0 & Small & $\begin{array}{l}\text { Without inhibition } \\
\text { zone, some } \\
\text { restricted colonies }\end{array}$ & Limited efficacy & \\
\hline $\begin{array}{l}\text { Dyed with } \\
\text { Mad Color and } \\
\text { mordanted with } \\
2 \% \text { mimosa }\end{array}$ & 0 & None & $\begin{array}{l}\text { Without inhibition } \\
\text { zone, without } \\
\text { multiplication }\end{array}$ & Satisfactory effect & \\
\hline $\begin{array}{l}\text { Dyed with } \\
\text { Mad Color and } \\
\text { mordanted with } \\
8 \% \text { mimosa }\end{array}$ & 0 & None & $\begin{array}{l}\text { Without inhibition } \\
\text { zone, without } \\
\text { multiplication }\end{array}$ & Satisfactory effect & \\
\hline $\begin{array}{c}\text { Dyed with } \\
\text { Mad Color and } \\
\text { mordanted with } \\
2 \% \text { mimosa / } \\
4 \% \text { alum }\end{array}$ & 0 & None & $\begin{array}{l}\text { Without inhibition } \\
\text { zone, without } \\
\text { multiplication }\end{array}$ & Satisfactory effect & \\
\hline $\begin{array}{c}\text { Dyed with } \\
\text { Mad Color and } \\
\text { mordanted with } \\
8 \% \text { mimosa / } \\
15 \% \text { alum }\end{array}$ & 0 & None & $\begin{array}{l}\text { Without inhibition } \\
\text { zone, without } \\
\text { multiplication }\end{array}$ & Satisfactory effect & \\
\hline
\end{tabular}


is taken into account, the smallest values of the mean UVB transmission and consequently, the best protection against UVB radiationare obtained for knitted fabrics with Mad Color, previously mordanted with $8 \%$ mimosa, $15 \%$ alum and for the knitmordanted with $2 \%$ mimosa and $4 \%$ alum.

\section{Antibacterial activity evaluation}

SR EN ISO 20645/2005 standard (Determination of antibacterial activity-agar diffusion plate test): the manitolsalt Aagar gel is prepared for the lower layer without bacteria. $(10 \pm 0,1) \mathrm{mL}$ gel is placed into each sterilized Petri dish and allow gel to solidify. Another amount of gel is prepared for the upper layer and cooled to $45^{\circ} \mathrm{C}$ in a water bath. $150 \mathrm{ml}$ of gel is inoculated with $1 \mathrm{~mL}$ of Staphylococcus aureus bacterial working solution $\left(1-5 \times 10^{8} \mu \mathrm{g} / \mathrm{mL}\right)$. The container is vigorously stirred for the uniform distribution of bacteria. $(5 \pm 0,1) \mathrm{mL}$ are introduced in each Petri plates and allow the gel to solidify. The textile specimens ( $2 \mathrm{~cm}$ diameter) are placed on the surface of the nutrient medium and then incubated at $37^{\circ} \mathrm{C}$ for $18 \mathrm{~h}$ $-24 \mathrm{~h}$. The antibacterial evaluation is based on the absence or presence of bacterial multiplication in the contact area between the agar and the test specimen and on the occurrence of a possible inhibition area around the specimens. Inhibition zones were calculated using the following formula: $H=(D-d) / 2$, where: $H$ is the inhibition zone in $\mathrm{mm} ; D$ - the total diameter of specimen and inhibition zone in $\mathrm{mm}$; $d$ - the diameter of specimen in $\mathrm{mm}$.

Table 5 shows the micrographs of antibacterial activity of undyed and dyed fabrics against Staphylococcus aureus.

Hier the data about methodic that you have used for antibacterial activity determining must be described.

According to EN ISO 20645:2004 standard, the treatment is considered effective if the inhibition zone is $\geq 1-0 \mathrm{~mm}$ and no growth under specimen is detected, whereas $0 \mathrm{~mm}$ inhibition zone and slight growth is evaluated as limited effect and without colonies multiplication is evaluated as satisfactory effect.

The inhibition zone is zero $\mathrm{mm}$ for all the tested samples. The untreated cotton knit doesn't have any antibacterial activity. The efficacy of the fabrics mordanted with mimosa tannin and mimosa tannin/alum is limited, a small growth of bacteria colonies is observed on the materials. The dyed fabrics have a "satisfactory effect" as long as any bacterial growth is detected on their surface. Different studies [8] reported the antibacterial activity of the madder dye, the responsible compounds for this effect being considered alizarin, purpurin and quinizarin [30-32] wich affect the bacterial cell wall. Due to their redox potential, these molecules form complexes with amino acids, inhibiting the synthesis of proteins and the bacterial growth [33].

\section{CONCLUSIONS}

Knit cotton fabric was premordanted with mimosa tannin and mimosa/alum and then dyed with Mad Color powder extracted from Rubia Tinctoria. Being a complex mixture, it is very difficult to identify the exact components responsible for dyeing of textiles, the UV-Vis spectra suggesting as main components ruberythricacid, lucidinprimeveroside and alizarine.

The exhaustion degree, spectrophotometrically evaluated, has demonstrated the presence of dye and mimosa tannin in the after dye bath. Colour fastness to washing and light is poor while the fastness to perspiration and rubbing is moderate. The mordanted and dyed knitted fabrics highly improve the UV protection ability by lowering the penetration of UV rays through the materials. Moreover, the dyed fabrics inhibit the bacterial growth, probably due to presence of madder specific molecules on the material surface of the fiber.

\section{ACKNOWLEDGMENTS}

This study was supported by the Executive Unit for Financing Higher Education, Research, Development and Innovation (UEFISCDI) through the project No. 55/2017 UV-SHIELD in the frame of PN III Program, EUREKA Traditional projects.

Publishing has been funded also by Ministry of Research and Innovation, by Program 1 - Development of the national system for research-development, Subprogram 1.2 Institutional performance - Projects for funding excellence in RDI, Contract no. 6PFE from 16.10.2018.

\section{BIBLIOGRAPHY}

[1] Schweppe, H., Winter, J. Madder and alizarin artist' pigments: a handbook of their history and characteristics, In: E. West FitzhHugh, Washington and Oxford, 1997.

[2] Sukenik, N., Iluz, D., Amar, Z., Varvak, A., Workman, V., Shamir, O., et al. (2017) Early evidence (late $2^{\text {nd }}$ millennium BCE) of plant-based dyeing of textiles from Timna, In: Israel. PLoS ONE 12(6): e0179014. https://doi.org/10.1371.

[3] Derksen, G.C.H., Niederländer, H.A.G., van Beek, T.A. Analysis of anthraquinones in Rubiatinctorum L. by liquid chromatography coupled with diode-array UV and mass spectrometric detection, In: J. Chromatogr., A 978 (2002), pp. 119-127.

[4] Rafaëlly, L., Héron, S., Nowik, W., Tchapla, A. (2008) Optimisation of ESI-MS detection for the HPLC of anthraquinone dyes. In: Dyes Pigm., 77, pp. 191-203.

[5] Chenciner, R. (2000) Madder Red: A history of luxury and trade. In: Caucasus World, Curzon Press;

[6] Perumal Samy, Peter Natesan Pushparaj and Ponnampalam Gopalakrishnakone, A compilation of bioactive compounds from Ayurveda, In: Bioinformation 3(3), pp. 100-110 (2008) http://www.bioinformation.net/ 003/002100032008.pdf.

[7] Manojlovic, N.T., Solujic, S., Sukdolak, S. \& Milosev, M. (2005) Antifungal activity of Rubiatinctorum, Rhamnusfrangula and Caloplacacerina. In: Fitoterapia, 76, pp. 244-246. 
[8] Kalyoncu, F., Cetin, B. \& Saglam, H. (2006) Antimicrobial activity of common madder (Rubiatinctorum L.). In: Phytother. Res., 20, pp. 490-492

[9] Guinot, P., Lemoine, A., Joos, M.-É., Pélegrin, S., Gargadennec, A., Rapior, S., \& Poucheret, P. (2010) Evaluation of antioxidant and antiproliferative activities of dyeing plants, In: Acta Botanica Gallica, 157:1, 37-43, DOI: 10.1080/12538078.2010.10516187.

[10] Yasui, Y. \& Takeda, N. (1983) Identification of a mutagenic substance in Rubiatinctorum L. (madder) root, as lucidin. In: Mut. Res. Lett., 121, pp. 185-190.

[11] Kawasaki, Y., Goda, Y. \& Yoshihira, K. (1992) The mutagenic constituents of Rubiatinctorum. In: Chem. Pharm. Bull., 40, pp. 1504-1509.

[12] Bechtold, T. (2009) Natural colorants - quinoid, naphthaquinoid and anthraquinoid dyes. In: Bechtold T., Mussak R. (eds) Handbook of natural colorants. In: John Wiley \& Sons, Ltd., pp. 151-182.

[13] Grifoni, D., Bacci, L., Lonardo, S.D. et al. (2014) UV protective properties of cotton and flaxfabrics dyed with multifunctional plant extracts. In: Dyes and Pigments, 105, pp. 89-96.

[14] Hupel, M., Poupart, N., Gall, E.A. (2011) Development of a new in vitro method to evaluatethe photoprotective sunscreen activity of plant extracts against high UV-B radiation. In: Talanta, 86, pp. 362-371;

[15] https://www.nms.ac.uk/turkey_red/colouring_the_nation/research/dyeing_and_printing_techniques/the_turkey_red_ process.aspx date accessed $21 / 01 / 14$.

[16] Chenciner, R., Madder Red: A history of luxury and trade, In: Curzon Press, 2000.

[17] Mathe, C., Mazzitelli, J.-B., Vieillescazes, C. Madder: from the plant to the museum objects, In: e-conservation Journal 5, 2017, accesed on 27 January 2018, http://e-conservation.org/65-madder-from-the-plant-to-museumobjects.

[18] Bioactive Natural Products (Part G) By Atta-ur-Rahman, Elsevier, Mar 1, 2002 - Science.

[19] Zhang, X., Good, I. and Laursen, R. Characterization of dyes in ancient textiles from Xinjiang, In: J. Arch. Sci. 35, pp. 1095-1103 (2008).

[20] Zhang, X. and Laursen, R.A. Development of mild extraction methods for the analysis of natural dyes in textiles of historical interest using LC-Diode Array Detector-MS, In: Anal. Chem. 77, pp. 2022-2025 (2005).

[21] Daniels, V., Devièse, T., Hacke, M. and Higgitt, C. http://www.britishmuseum.org/pdf/BMTRB_8_Daniels_et_al.pdf.

[22] http://sites.northwestern.edu/vanduyne/files/2012/10/2007_Whitney.pdf.

[23] Mouri, C., Laursen, R. (2012) Identification of anthraquinone markers for distinguishing Rubia species in madderdyed textiles by HPLC. In: Microchim. Acta, 179, pp. 105-113.

[24] Derksen, G.C.H., Naayer, M., van Beek, T.A., Capelle, A., Haaksman, I.K., van Doren, H.A., de Groot, Æ. (2003) Chemical and enzymatic hydrolysis of anthraquinone glycosides from madder roots. In: Phytochem Anal, 14, pp. 137-144.

[25] Ishii, Y., Okamura, T., Inoue, T., Fukuhara, K., Umemura, T., Nishikawa, A. (2010). Chemical structure determination of DNA bases modified by active metabolites of lucidin-3-Oprimeveroside. In: Chem Res Toxicol, 23, pp. $134-141$.

[26] Hofenk de Graaff, J.H., The colourful past: Origins, chemistry and identification of natural dyestuffs, In: AbeggStiftung and Archetype Publications Ltd., Riggisberg and London, 2004.

[27] Henderson, R.L., Rayner, C.M., Blackburn, R.S. (2013) Isolation and extraction of lucidin primeveroside from Rubia tinctorum L. and crystal structure elucidation. In: Phytochemistry 95, pp. 105-108.

[28] Draft Indian Standard Textiles dyestuff - rubia dye (madder) - specification http://www.bis.org.in/sf/txd/TXD07 (11694)_21072017.pdf.

[29] De Reguardati, S., Lemonnier, A. (2012) La garance des teinturiers. Proposition d'activitésautour des molécules de la garance. Museum national d'histoirenaturelle. In: Eco-designed functionalization of polyester fabric Doctoral dissertation by Tove Agnhage, https://hb.diva-portal.org/smash/get/diva2:1128277/FULLTEXT01.pdf.

[30] Dzoyem, J.P., Melong, R., Tsamo, A. et al. (2017) Cytotoxicity, antioxidant and antibacterial activity of four compounds produced by an endophytic fungus Epicoccumnigrum associated with Entadaabyssinica. In: Brazilian Journal of Pharmacognosy, 27, pp. 251-251 East A J (2009).

[31] Lee, J.-H., Kim, Y.-G., Yong Ryo, S. et al. (2016) Calcium-chelating alizarin and other anthraquinones inhibit biofilm formation and the hemolytic activity of Staphylococcus Aureus. In: Scientific Reports, 6(19267), pp. 1-11.

[32] Yen, G.C., Duh, P.D., Chuang, D.Y. (2000) Antioxidant activity of anthraquinones and anthrone. In: Food Chemistry, 70, pp. 437-441.

[33] Alihosseini, F. (2016) Plant-based compounds for antimicrobial textiles. In: Sun G (ed) Antimicrobial textiles. Elsevier, Ltd., pp. 155-195.

\section{Authors:}

IULIANA DUMITRESCU ${ }^{1}$, OVIDIU GEORGE IORDACHE¹ , ELENA-CORNELIA MITRAN, DANA STEFANESCU², ELENA VARZARU ${ }^{1}$, MARIANA PISLARU², RODICA CONSTANTINESCU ${ }^{2}$

${ }^{1}$ The National Research Development Institute for Textiles and Leather, Bucharest, Romania 2SC Tanex SRL, Bucharest, Romania

Corresponding author:

IULIANA DUMITRESCU

e-mail: iuliana.dumitrescu@certex.ro 